\title{
Learning for Job: A Study on Dual TVET System in the Context of Nepal.
}

\section{- Nimananda Rijal-PhD.}

\begin{abstract}
.
Learning for Job is a concept of learning by doing, learning by imitation, and learning by innovation, these three aspects affect the pedagogy of technical education. Therefore this TVET is a complex process that is directly linked to fulfilling the day-to-day requirement of the production in the industrial setup. Nepal has only two systems of TVET, formal and non-formal, the formal system has only on the job training (OJT) that is for 3 to 4 months, it depends in the situation, nonformal is combined with the training and experience, some time with the experience standardized the level of achievement, it indicates that both the system are not functioning well since their competency is lacking to the market. A market competency is required for the job, therefore to solve this problem, a dual TVET system should come in with proper planning and investment. The research found out, the people who are aware of the TVET and market competency, have rated $85 \%$ with 4.20 mean of the respondent and they have also given suggestions to provide industries incentives for those who have accepted the trainees to train in the form of dual TVET, the instructor also needs to work and train the trainees at the same time, the trainees need to pay the wages properly as per their work by the industries so that they will have the motivation of getting a job and earning for living. The government should start the program in the piloting phase to identify the problems and strengths of the program before venturing at a go. Trainees should have employment almost 95 percent; this indicates the success of the program.
\end{abstract}

Key words: Dual system of TVET, apprenticeship, employment, learning for job. 


\section{Introduction:}

'Dual systems of vocational education and training (VET) are specific training systems that aim at systematically combining the advantages of training in a company and education in a vocational school'(Bärbel Fürstenau, Matthias Pilz, and Philipp Gonon, 2014).Transition to the youth in to the field of work should be the priority to all stake holders of educational system. In Nepal, TVET has not been shaped as per the tradition of the country; therefore there is a mismatch in between TVET and employment. 'There are polytechnics run by the CTEVT, Ministry of education, Secondary education up to 12 grades, universities for engineering education and NSTB for the skill labeling work. All these have a concern to produce quality output that fits to the market' 'Gross domestic product of the country 'depends on exporting goods, production of goods.

Nepalese society is self-reliant, they have developed technology as required to survive such as plantation of medicinal herbs, water shade management, food production, construction technology, fiber processing, use of wool to produce many items, and many more and the richness has added by its 'geographical diversity and many ethnic communities. All of these communities have some kind of traditional knowledge associated with their life from time immemorial. They have contributed their wisdom, knowledge, skill and technologies on sound use of the natural resources, conservation and restoration' (Nepal, 2017). The technology was handed over generation to generations, the handing over was carried out by father to their heirs, at present terms this is called apprenticeship mode of learning. They have stored great wisdom of surviving without destroying the natural balance of life; even the wheels were created from wooden structure and pulled by ox, horse and other animals. Still these traditional skills are highly needed in modern ways, how to make competent to the people as required by the market/ industries. In this context dual TVET system will be viable to fulfill the demand of the market with the skill of global competent.

\subsection{Problem Statement.}

Technical and Vocational education has been introduced in Nepal since the start of formal education begins after the overthrown of Rana regime, informally apprenticeship was in the practice to fulfill the requirement of the society in the different sectors form tanning to construction. When the population increased and the demand of the workforce increased, 
apprenticeship mode of learning lacked to meet the demand of the market, then after the formal technical and vocational education started in the country since 1988, in 1954 National Education Planning Commission ( NNEPC) established and its main function was to survey the education of Nepal and recommend, the commissions one of the recommendation was establishment of 39 multipurpose high school in each district, that time there were 39 districts of Nepal. This is the formal beginning of technical and vocational education of Nepal. Since then the establishment of Technical training institute increased and UMN also established Butwal Technical Institute in 1969 and this was one of the pioneering institute to train the skilled youth required to the market. The model of the teaching and learning was excellent.

The education and TVET education also have mismatch to the requirement of the market and technical training. This has been a setback in the development of the country and creating unemployment also.

\subsection{Objectives of the Study:}

i. To identifying the relevancy of dual TVET system in the context of unemployment problem solving in the context of Nepal.

ii. To identify the approaches for implementing dual TVET system and preparedness of the state. iii. Conceptual analysis of the dual TVET system among the instructor of the TVET.

\subsection{Study Methodology.}

The questionnaire will be circulated by hand and the use of Google form for those who are not easy to reach due to COVID-19.The data on dual TVET will be collected from the professional who are engaged in the TVET system. Most of them will be engaged in the TVET system of Nepal. These are from the background of Diploma level to Ph.D. level of education. The collected data will be analyzed by using SPSS to identify their views on the Dual TVET system required to produce competent human capital as required to the market. The literature will also be reviewed to identify the significance and use of Dual TVET system in the country.

\section{Literature Review.}

There are many countries in Europe they have adapted dual technical vocational education; it has helped to reduce the unemployment and fulfilling the human resource requirement. German is one 
of the countries that have followed. The system "strongly supports a successful transition of young people from school to work and to guarantee a skilled workforce as a prerequisite for a successful economy. In addition it plays a role in educating young people. Consequently, the central goal of VET in the dual system is to help students attain and develop competence in action so that they can meet current and future professional challenges and participate in defining their vocational lives”(Bärbel Fürstenau , Matthias Pilz, and Philipp Gonon, 2014). All most all countries Technical, Vocational Education and Training (TVET) plays a vital role on producing skilled human resources but it differs in governance, timing and delivery methods'(Lerman, 2013). Apprenticeship was an old tradition method of Nepal, it cannot support the market demand, and therefore dual TVET system has to be delivered to keep up the knowledge and skill competency required to the market. Social status of education depends on its success the educational program. The functioning of dual VET system Successful depends on the social status of this education program.'(Thomas Bolli and Ladina Rageth, 2016). Dual TVET helped to lower the unemployment. 'Another area of training intervention, which has attracted a great deal of attention especially in developing countries, is enhancing traditional apprenticeships in the informal economy, as it is impossible to stop production in order to engage in training. The apprentice model is an effective model of learning because it is based on the assumption that the young learner is most easily taught. The learner learns his basic competency skills in the context of genuine work situations. This contrasts with most existing vocational training programmes in which the rewards early on are limited, and in which students are older and have learned the basic competency skills out of context'(Singh, 2000). 'In Nepal, more than 70 per cent of the economically active population is involved in the informal economy. Due to changing patterns of employment, the informal economy is rapidly expanding' (ILO, ILO/Nepal, 2021). The problem of Nepal is to how to prepare competent workforce that are capable to take up jobs in international arena as well since its economy's considerable portion is from remittance. According to the report of World Bank, 24.1 percent of remittance contributing in the economy of Nepal(Bank, 2020). The youth who go for employment in foreign countries are not so aware of the profession, since the educational system has not been preparing them for world of work and those who are trained are not capable of taking up challenging jobs competing with the well trained people of other countries, therefore they are denied to take up high paid works as well. 
'However, given the conditions of work in the informal economy in developing countries, the issue is one of converting the cheap workforce model into a model in which active learning is designed to develop a variety of process skills in the workforce. Such on-the-job training needs to be recognized as part of the educational system, as a form of deliberate rather than accidental learning' (Singh, 2000). Nepal education system is more inclined towards white color jobs like a study of Srilanka found out as 'Most parents who expect their children to be employed in white-collar jobs, motivate their children to receive extra tuition and to memorize lessons and pass examinations at every level from Grade one to G.C.E. Advanced Level with high grades to enter State Universities which provide free higher education, neglecting other factors of child development, producing an unskilled, non-innovative, emotionally weak young generation who only "know" but pathetically fail to "do"(Grero, 2019). The competent young generation coming up for the future is the concern of all countries.

Nepal and Its Education System: 'The study was carried out as 'An apex body of education is the Ministry of education; established in 1951, Now it is named as Ministry of Education, Science and Technology (MoEST) with the responsibility of developing policies, programs, plans, implementing and management of overall development of education, science, and technology of the country (MoEST, 2018). The ministry has been providing policy-level guidance for Technical and Vocational Education. CTEVT, the semiautonomous body of the ministry has been conducting technical and vocational education in the country with the authority of affiliation to private institutes. School Education is 12 years, bachelor 4 years, master 2 years, M. Phil. 18 months, and Ph.D. 3 to 7 years. A higher level of education has been conducting by universities, including Engineering and Medical science. There are 13 universities in the country some more are in the pipelines to establish by the provincial governments'(N. Rijal \& M. Rijal, 2020)The technical education is having three different entities to conduct technical and Vocational education, those are CTEVT, the Diploma Program in different faculties, which is an autonomous body under the ministry of Education and it also runs Technical SLC program for SLC pass for the duration of one and half years, these are eligible for Diploma Level, the second one is HSEB which runs school based technical education, and NSTB a department of CTEVT, which is responsible to validate informal and Non-formally learnt skills. 
'The links to the labor market and specifically to employers are a key challenge for sustaining apprenticeship systems, as well as for the task of researching them. As such, policy maker (and researcher) consideration of apprenticeship should take account of the capacity and commitment of employers. Another key challenge for apprenticeship is related to the relative attractiveness of this pathway for individuals. What is clear from this study is that the development of a strong apprenticeship system requires the buy-in of both employers and individual learners, and as such the necessity to identify and implement incentives effectively cannot be underestimated. Governments can play a key role in realizing the potential incentives for both employers and learners; thereby yielding benefits for all parties engaged in apprenticeships' (Maia Chankseliani and Aizuddin Mohamed Anuar, 2019) Dual education system should also have incentive to the employer and the learner for its sustainability. 'The fact that apprenticeship allows individuals to earn wages while learning can serve as a very strong incentive for participation. In some contexts when the individual joining the labor market directly rather than by pursuing an apprenticeship may earn more, why should have to join them in the apprenticeship mode of TVET' (Maia Chankseliani and Aizuddin Mohamed Anuar, 2019). This short of problem persist even in Nepal, therefore the dual TVET system need to pay to the learner as their incentives while they are working in the industries and even in the learning institutes. Unskilled labor drain is rampant in Nepal, how to motivate such youth in the TVET system is a challenge, labor drain could be an economic factor that would have been pushing them to be cheap labor in the market.

According to ILO 'the unemployment rate for youth aged 15-29 is 19.2 per cent compared to 2.7 per cent for the whole population. Over 400,000 young people are estimated to enter the labor force every year. These figures indicate the quantitative dimension of the employment challenge in Nepal'(ILO, 2021). Nepal is facing challenges in the workplace also, they are not up to the level of quality to work, this also append to unemployment and low salaries compare to the living expensed required and expectation from the family, in the same report the ILO pinpointed as 'More challenging for Nepal is the quality aspect of employment, which is associated with predominance of employment in the informal segments of the economy where productivity and earnings are low and conditions of work are poor(ILO, 2021). 


\section{Data Analysis.}

The questionnaire was sent by the Google form, and some by handed over by hands to answers, all together 20 TVET professional has answered the questions. The qualification of the respondent is higher than Diploma Level in Technical education, the Ph.D. those answered are involved in TVET in different form and 55 percent male and 45 percent female participated in the to fill the questionnaire. Dual TVET system becoming the popular in some countries, it will help to reduce the unemployment to the youth and reduce the unskilled labor drain.

\section{Table 1: Demograhic analysis.}

\begin{tabular}{|c|c|c|c|c|c|}
\hline \multicolumn{3}{|c|}{ Qualification Analysis } & & & \multirow[t]{2}{*}{ Gender } \\
\hline & Nos. & $\%$ & & & \\
\hline Diploma & 2 & 10.0 & & Nos. & $\%$ \\
\hline Master & 16 & 80.0 & Male & 11 & 55.0 \\
\hline \multicolumn{6}{|l|}{ Engineering. } \\
\hline $\mathrm{PhD}$ & 2 & 10.0 & Female & 9 & 45.0 \\
\hline Total & 20 & 100 & Total & 20 & 100.0 \\
\hline
\end{tabular}

Source: Primary Data

The research analysis carried out by using the SPSS statistical tool to find out the views of the people in the different areas as per asked questions. The questions were mainly focused on Dual TVET system and its benefit in the context of Nepal. Will it be helpful to solve unemployment rate of Nepal. Unemployment rate of youth is worrisome issue to the policy makers. 
Table 2: Analysis of questionnaire 1-7

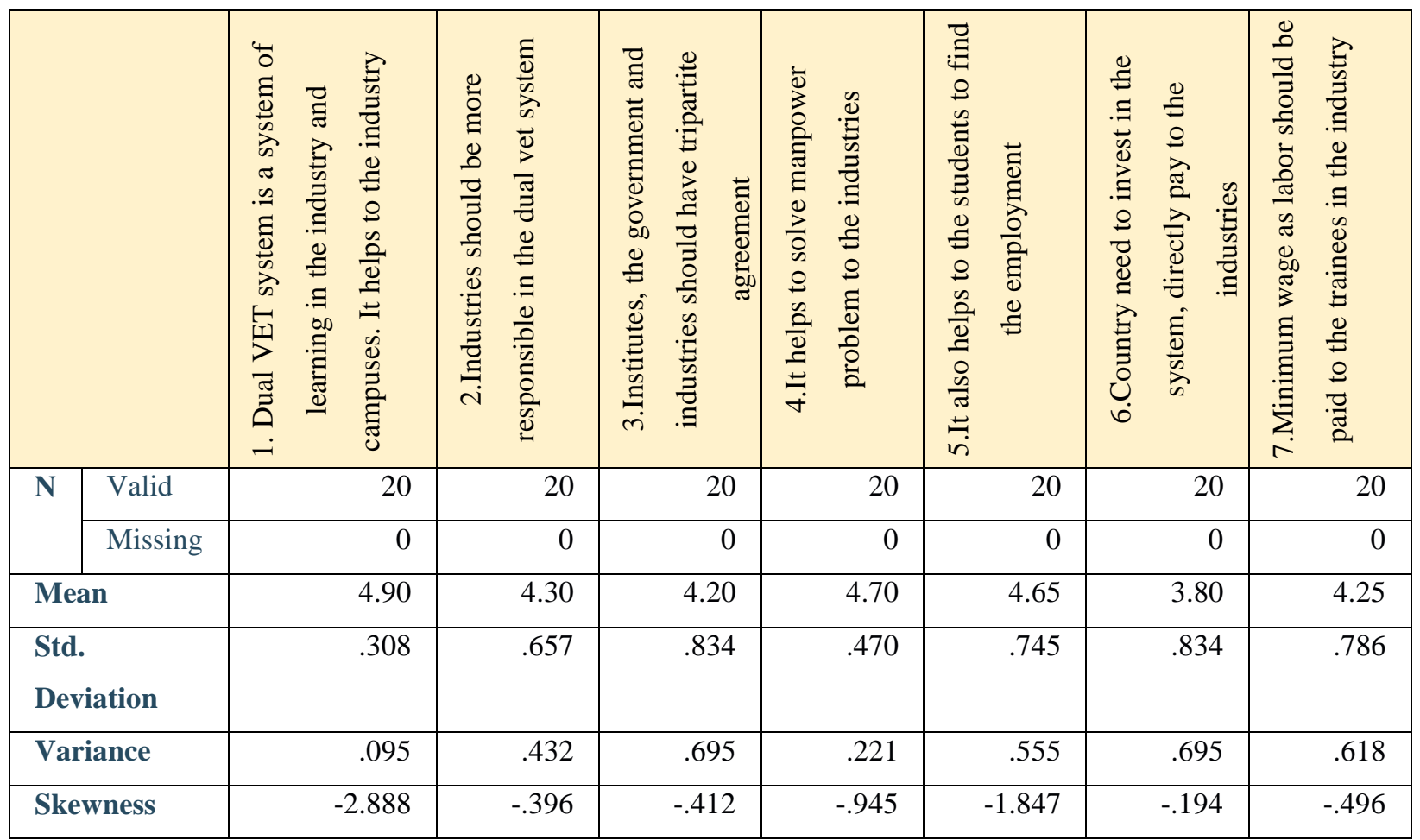

Source: Primary data

The average mean of the questions 1 to 7 is 4.4., it indicated that the dual system of technical and vocational education is vital to solve human capital development with the skill and knowledge. The concept on dual system found similar in all participants, institutional and industrial learning combined to produce competent graduates to fit in the industrial setups. The mean on country need to invest in the system directly pay to the industry in order to motivate industries to take part in the human resource production is 3.80 , there is some hesitation but the majority of the participants agreed it should be done. 'If skewness is 0, the data are perfectly symmetrical, although it is quite unlikely for real-world data. If skewness is less than -1 or greater than 1 , the distribution is highly skewed; If skewness is between -1 and -0.5 or between 0.5 and 1 , the distribution is moderately skewed; If skewness is between -0.5 and 0.5 , the distribution is approximately symmetric' (Kristian.klima, 2021) The Skewness of Question 1 -2.88, and Q-5 1.84 , both the answers are inclined one side it means the answers and normally distributed; other answers are moderately distributed. 
Table 3 Analysis of Questions 8-14

\begin{tabular}{|c|c|c|c|c|c|c|c|c|}
\hline & 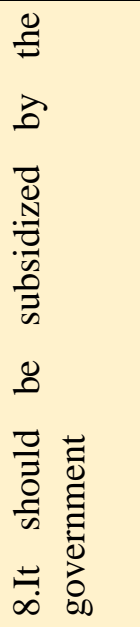 & 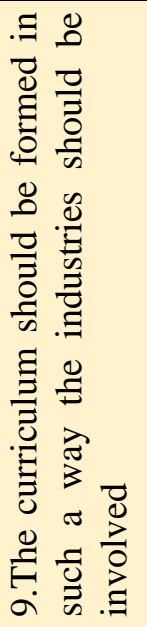 & 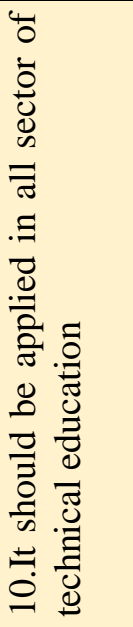 & 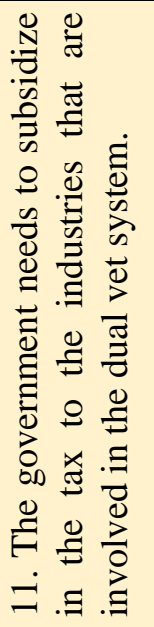 & 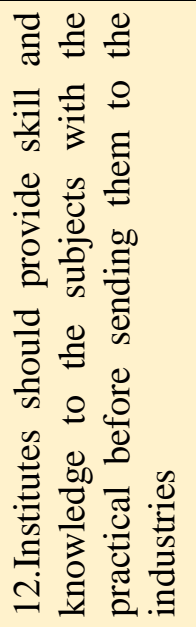 & 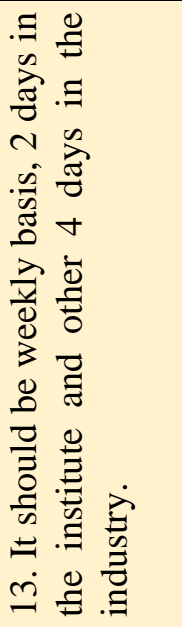 & 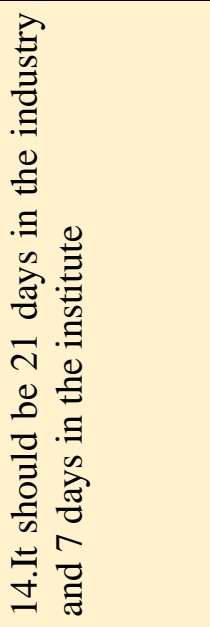 \\
\hline \multirow[t]{2}{*}{$\mathbf{N}$} & Valid & 20 & 20 & 20 & 20 & 20 & 20 & 20 \\
\hline & Missing & 0 & 0 & 0 & 0 & 0 & 0 & 0 \\
\hline \multicolumn{2}{|c|}{ Mean } & 4.20 & 4.70 & 4.30 & 4.35 & 4.65 & 3.75 & 3.85 \\
\hline \multicolumn{2}{|c|}{$\begin{array}{l}\text { Std. } \\
\text { Deviation }\end{array}$} & .951 & .470 & .865 & .813 & .587 & 1.020 & .933 \\
\hline \multicolumn{2}{|c|}{ Variance } & .905 & .221 & .747 & .661 & .345 & 1.039 & .871 \\
\hline \multicolumn{2}{|c|}{ Skewness } & -.440 & -.945 & -.663 & -.766 & -1.521 & .228 & .325 \\
\hline
\end{tabular}

Source: Primary Data.

The highest mean in between Q. No. 8-14 is 4.70 and lowest mean 3.7 of 13, which is also highly desirable, the average mean is 4.25 , it indicates that the respondents are liked the concept and they understood what the question means and required to the country. If we convert it in the percent $85 \%$ people agreed in the statement for an example 4.20 mean indicates 84 percent people said the government need to subsidize the dual TVET in Nepal. 
Table 4: Q.15 -20.

\begin{tabular}{|c|c|c|c|c|c|c|c|}
\hline & 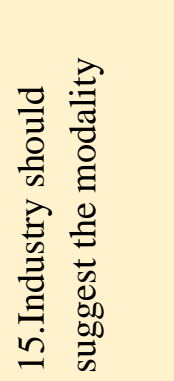 & 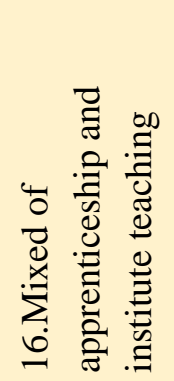 & 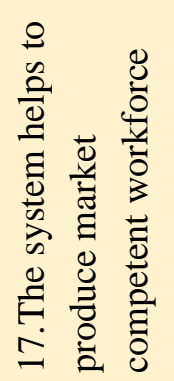 & 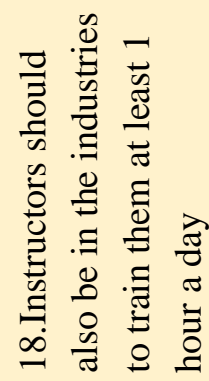 & 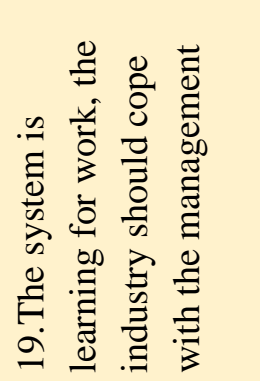 & 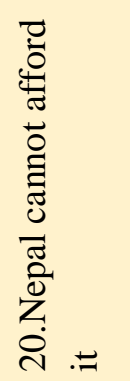 \\
\hline \multirow[t]{2}{*}{$\mathrm{N}$} & Valid & 20 & 20 & 20 & 20 & 20 & 20 \\
\hline & Missing & 0 & 0 & 0 & 0 & 0 & 0 \\
\hline \multicolumn{2}{|c|}{ Mean } & 3.80 & 4.00 & 4.05 & 4.15 & 4.30 & 2.80 \\
\hline \multicolumn{2}{|c|}{ Std. Deviation } & .951 & .562 & .999 & .933 & .571 & 1.399 \\
\hline \multicolumn{2}{|c|}{ Variance } & .905 & .316 & .997 & .871 & .326 & 1.958 \\
\hline \multicolumn{2}{|c|}{ Skewness } & .033 & .000 & -.108 & -.325 & -.038 & .266 \\
\hline
\end{tabular}

Source Primary data

Q.15 with mean 3.80 indicated that the industry should suggest the modality and Q.16 suggested with the mean of respondents' outcome 4.00; it means that Industrial practice and workshop teaching in training institute should be side by side. Q.17. highlighted the importance of dual system with the mean of 4.15; the competency counts in

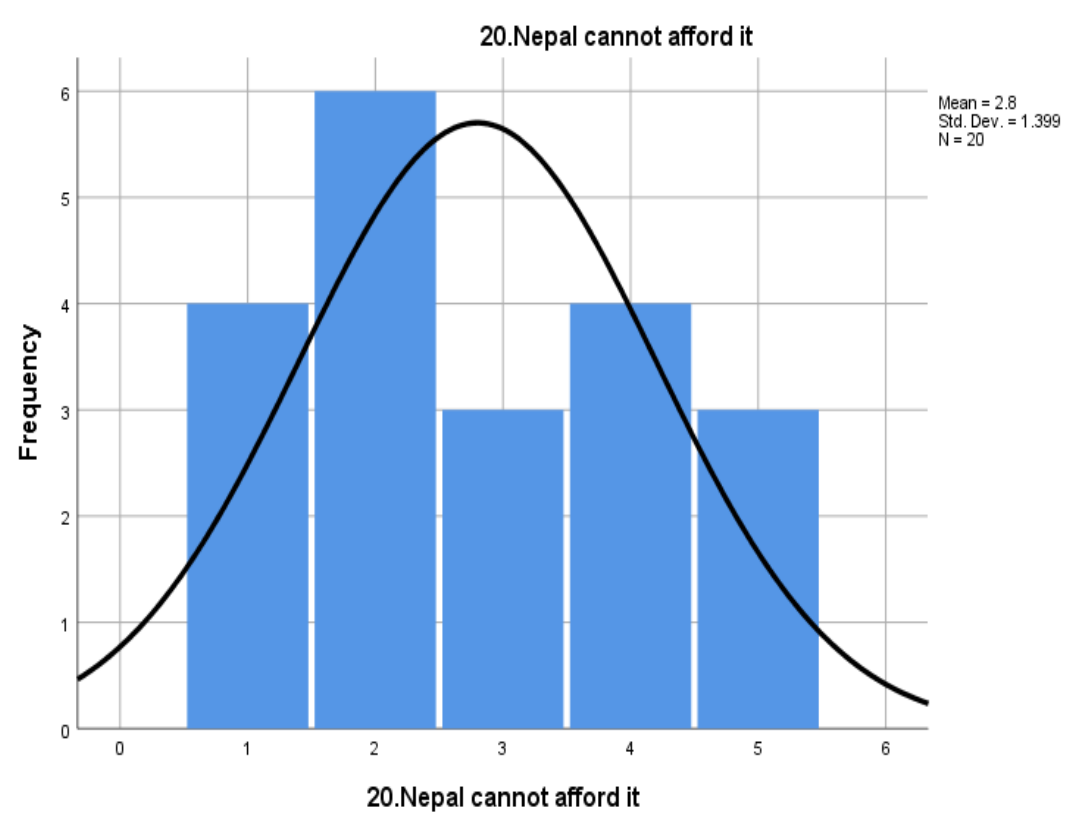
the market not only the certificates. 
Q.18 asked to the teacher should be in the industry during the time of apprentice of the trainees so that they have a chance to learn and earn to the teachers also, at the same they will support to the students. Some time, the industry may deny to intake the trainees, they should be allowed and cope with them, since these are the product of national system. Q 20 asked the view of the people on dual vocational system, they rejected the motion. Nepal should go for it. 50 percent people in favor of implementing dual VET system in Nepal another 15 percent are neutral. The question was asked as negative tone, and then respondent rejected the statement, the rejection is the positive in answer.

\section{Research Findings.}

i. The concept of the people, particularly those working in the field is clear that is 'the TVET should be in the classroom and industrial set up learning' to produce competent human resource mean value of the respondent is 4.0 and the 85 percent; the research found the conceptual clarity on the issue of dual TVET system.

ii. The research found the know how the individual both the way helps to reduce the unemployment problem of the trainees. On this regard Q.4 is more relevant with the mean value of 4.7 .

ii. The research also found out the industries should be subsidized those who are taking the participants for dual system TVET, in this issue the government should be serious, the mean value of the statement is 4:20, this indicates the people knew, how to make sustainable dual TVET system and linking properly with the market, it could be a motivating factor to the industries to accept the graduates.

\section{Recommendations:}

a) Dual TVET is required to produce market competent human capital; this will be the driving force of the development. The government needs to introduce dual TVET System systematically.

b) The industries should be involved in the modality of dual TVET system, it is highly required since there are some seasons the industrial product works are slower, and this time the institute should have the workshop practice and teaching. 
c) Government need to subsidize the tax and pay half of the wages during the time of Industrial work of the trainees, this should be in the cost sharing basis, it will attract to the industries to accept the trainees of the dual TVET system.

d) Institutional workshops also need to setup in the environment of the industries, such as machines, working conditions, use of tools and production chain as per the industrial requirement.

e) Collaborating required of the technical providing Institutes to the Industries in production and training.

\section{Conclusion.}

The research demands the dual TVET system to produce the market competent workforce and the workforce will also be earning while learning. The dual system of TVET will encourage the industrialists as well the training institute with the intervention of the government subsidies during the time of workshop practices. Dual TVET system at the present context of Nepal found suitable to reduce youth unemployment of Nepal, according to the data of ILO estimation in 2019, the youth unemployment rate in Nepal was at 4.57 percent(O'Neill, 2021). The approach will be beneficial to all the developing and developed country also.

\section{Declaration.}

There is no conflict of interest, no grant received for the research and the research ethics was completely followed during the research process.

The end. 


\section{Bibliography}

Bank, W. (2020, Dec 1). https://data.worldbank.org/indicator/BX.TRF.PWKR.DT.GD.ZS?locations=NP. Retrieved 11 21, 2021, from https://data.worldbank.org/indicator/BX.TRF.PWKR.DT.GD.ZS?locations=NP: https://data.worldbank.org/indicator/BX.TRF.PWKR.DT.GD.ZS?locations=NP

Bärbel Fürstenau, Matthias Pilz , and Philipp Gonon. (2014). The Dual System of Vocational Education and Training in Germany: What Can Be Learnt About Education. Research Gate, 427-460.

Bärbel Fürstenau, Matthias Pilz , and Philipp Gonon. (2014). The Dual System of Vocational Education and Training in German What Can Be Learnt About Education. The research Gate, 427-128.

Grero, M. L. (2019). MISMATCH BETWEEN THE EDUCATION SYSTEM AND THE JOB MARKET IN SRI LANKA WITH SPECIAL REFERENCE TO SOFT SKILL. Colombo: Author.

ILO. (2021, 12 12). https://www.ilo.org/kathmandu/areasofwork/employment-promotion/lang-en/index.htm. Retrieved 12 12, 2021, from https://www.ilo.org/kathmandu/areasofwork/employment-promotion/lang--en/index.htm: https://www.ilo.org/kathmandu/areasofwork/employment-promotion/lang--en/index.htm

ILO. (2021, 12 21). ILO/Nepal. Retrieved NoV 21, 2021, from ILO/Nepal,www.https://www.ilo.org/kathmandu/areasofwork/informal-economy/lang-en/index.htm: https://www.ilo.org/kathmandu/areasofwork/informal-economy/lang-en/index.htm

Kristian.klima. (2021, April). Good Data. Retrieved 11 14, 2021, from https://community.gooddata.com/metrics-and-maql-kb-articles-43/normality-testing-skewnessand-kurtosis-241: https://community.gooddata.com/metrics-and-maql-kb-articles43/normality-testing-skewness-and-kurtosis-241

Lerman, R. I. (2013). Skill Development in Middle Level Occupations:The Role of Apprenticeship Training. IZA Policy Paper No. 61, 33.

Maia Chankseliani and Aizuddin Mohamed Anuar. (2019, December ). Cross-country comparison of engagement in apprenticeships. A conceptual analysis of incentives for individuals and firms. International Journal for Research in Vocational Education and Training (IJRVET), 6(3), 261-283.

N. Rijal \& M. Rijal. (2020). An Overview of Technical, Vocational Education and Training (TVET) in the. SSRN, 32.

N.Rijal. (2019). Role of Technical and Vocational Education in Economic development. SSRN, 28.

Nepal, T. (2017, January 10, Tuesday). Travellers Nepal. Retrieved Oct 19, 2021, from https://travellersnp.blogspot.com/2017/01/indigenous-traditional-technologies-in.html?m=1: https://travellersnp.blogspot.com/2017/01/indigenous-traditional-technologies-in.html?m=1

O'Neill, A. (2021, July 14). https://www.statista.com/statistics/812273/youth-unemployment-rate-innepal/. Retrieved 1211,2021 , from https://www.statista.com/statistics/812273/youth- 
unemployment-rate-in-nepal/: https://www.statista.com/statistics/812273/youthunemployment-rate-in-nepal

Singh, M. (2000). COMBINING WORK AND LEARNING IN THE INFORMALECONOMY: IMPLICATIONS FOR EDUCATION, TRAININGECONOMY: IMPLICATIONS FOR EDUCATION, TRAINING. In M. Singh. Kluwer Academic Publishers.

Thomas Bolli and Ladina Rageth. (2016). Measuring the Social Status of Education Programmes: Applying a New Measurement to Dual Vocational Education andTraining in Switzerland . SSRN and KOF Working Papers, No. 403, March 2016, 33. 